\title{
A BUDDHIST PERSPECTIVE ON HEALTH AND SPIRITUALITY
}

\section{Conrad Harvey}

\author{
Abstract: This article gives a brief overview of some of the basic tenets of Bud- \\ dhism. Its particular emphasis is upon Buddhist expressions of spirituality, as \\ they are likely to be met with in a healthcare setting. Included are guidelines on \\ diet, attitudes to medicine, and beliefs and traditions around death and dying.
}

Keywords: Buddhism, healthcare, religion, spirituality.

\section{Introduction}

Buddhism provides a religious outlook from a fifth of all humanity. The ancient civilisations of India and China were profoundly affected by it and today it remains deeply influential in Sri Lanka, Burma, Thailand, Korea, Japan and the countries of the Himalayas; as well as those areas of India now settled by Tibetans in exile.

In the 2001 census there were 151,816 recorded Buddhists in Britain. However, that doesn't take into account those who regard themselves as Buddhists as well as Christians, or Jews, or Taoists, or hold any other concurrent form of faith. The census form made no provision for such people to be counted. There are also those who refuse to formally label themselves as 'Buddhists' because they perceive it to run counter to the principle of selflessness or egolessness.

The religion known in the West as Buddhism was founded around 500BCE in Northern India by Siddhartha Gautama, a young prince who became disillusioned with his wealthy lifestyle and went in search of Truth. He abandoned his riches and wandered throughout Northern India seeking an answer to the problems of old age, sickness and death. After a long and arduous quest which lasted several years, he finally awakened to the Truth and realized supreme wisdom or Enlightenment. From that point on he became known as the 'Buddha' which means 'Awakened One'. He spent the remaining forty-five years of his life teaching the Way or Path to overcome suffering in all its forms.

The Buddha didn't write anything down, but his words were transmitted orally through his followers and later formulated into teachings which Buddhists call the 'Dharma'. This teaching was eventually written down and transmitted to anyone who wished to hear it. Shortly before his death at the age of 80 , the Buddha brought together a group of his followers and founded a religious order - the 'Sangha' which has remained both the guardian and the embodiment of his teachings to this day.

These three aspects - the Buddha, the Dharma and the Sangha - are known to all Buddhists as the 'Three Refuges' or the 'Three Jewels'. For a sincere Buddhist these are not empty concepts: they point to the practical path of spiritual awakening which can be developed and used in daily life by all.

\section{Basic Beliefs}

The Buddhist 'Path of Life' offers prescriptions for the ethical and spiritual well-being of each individual and exhorts them to develop Wisdom and have Compassion towards all forms of life. For those who have not chosen a monastic way of life there are five basic precepts, undertaking the rule of training:

1. To refrain from killing (especially human life)

2. To refrain from taking that which is not given

3. To refrain from misuse of the senses and sexual misconduct

4. To refrain from lying or using false or harmful speech

5. To refrain from taking intoxicating drink or drugs which cloud the mind 
The core principles of Karma (the Laws of Cause and Effect), Samsara (the experience of dukka people's dissatisfaction or suffering with conditioned existence) and the possibility of Cessation of Suffering with a practical and realistic Path involving meditation, practice and study leading to Enlightenment or Realised Buddhahood, are all intrinsic to Buddhism.

The Path is Eightfold and defined as Right View, Thought, Speech, Actions, Livelihood, Meditation, Effort and Mindfulness.

\section{Buddhism and Healthcare}

The Buddha's teachings spread from India throughout Asia, even reaching as far as the Greek empire at one point (hence the Buddhist Greek monarch Melinder). To the East, they reached the areas known today as Japan, China and South East Asia. To the North countries such as Nepal, Tibet, Mongolia and Russia. Wherever it spread Buddhism often influenced that society's practice of healthcare.

The following serve as summarized contemporary guidelines to various health issues, however Buddhism lays stress on personal responsibility and motivation as the precepts are training principles rather than commandments. Each individual is free to make his or her own decisions.

\section{Diet}

Many Buddhists are vegetarian or vegan due to the $1^{\text {st }}$ precept and respect for other sentient beings. Some may have taken a precept which involves eating only one main meal a day. This is usually eaten before midday. However it is not uncommon to find non-vegetarian Buddhists as the Buddha asked his monks to eat whatever they got.

\section{Fasting}

An individual's health allowing, in all schools and traditions a one day fast is recommended on New Moon and Full Moon days. There are also other festival days such as Buddha's birthday, death day, his enlightenment, the first Sermon and others.

\section{Ablutions \& Toilet}

No particular guidelines.

\section{Attitudes to Medicine}

Buddhists generally have no problem taking any medicine that helps. Some Buddhists will be wary, and will wish to know the effects, of any drug which alters their emotional state or clarity of mind due to the 5th precept. However, the idea of the 5th precept is so that individuals do not perform harmful acts whilst intoxicated. So, prescribed medication, that may be intoxicating but which is healing or reduces suffering, is usually accepted. Nevertheless some Buddhists may favour alternative health remedies or may be reluctant to accept sedating medication for this reason.

\section{Transplantation}

There is some spectrum of Buddhist opinion on this issue. Ultimately many will have no religious objections since helping others is fundamental to Buddhist belief -and organ donation during life seems to be universally considered skilful and compassionatean act of supreme generosity. However some may decline transplants and organ donation occurring after death due to the belief that the mind may dwell within the body for some time after cardio respiratory death; whereby the body should not be moved for 72 hours, and where disruption of internal organs may be perceived to undermine the optimal dissolution of consciousness.

\section{Blood Transfusion}

No religious objections.

\section{Family Planning}

There is no established Buddhist doctrine although there is a general reluctance to tamper with the natural development of life. A Buddhist may accept all methods of family planning, but with different degrees of reluctance. The gravest of all is abortion or "killing a human to be". This is seen to be harming a living sentient being. Pills and condoms are much less serious, though condoms would be preferred for the same reason. Generally all Buddhist traditions condemn abortion and euthanasia.

\section{Birth}

Generally, no particular guidelines, although there is a tradition amongst Buddhists in some South East Asian countries for a basket containing some tools to be prepared for a baby boy and if the baby is a girl, for the cradle to contain needles and thread. 
There may even be a request for the umbilical cord to be salted and placed in an earthenware pot.

\section{The Dying Patient}

Consideration for the dying will vary depending on the Buddhist group. The most important consideration relates to the state of mind at the time of death for this will influence how the individual experiences the intermediate or "bardo" states and thereafter the character of rebirth. The state of the mind should be one of peace therefore the patient may wish to meditate and ask for a quiet place. They may wish for a Buddha figure to be in close proximity and a candle or incense stick may be used. Some may wish to receive counselling from a fellow Buddhist. Some form of chanting may be used to help reach the desired state of serenity. Some Buddhists may express a strong wish to die at home rather than in hospital. If possible this should be granted. Full discussion on the practical implications of this decision should be explored with the patient and relatives if terminal illness is diagnosed.

\section{Responsibility after death}

In many schools of Buddhism, there is no ritual requirement and normal hospital procedures are accepted. Some Buddhist schools have strongly held views concerning the way in which the body should be treated after death. It would be helpful to ascertain such views before death occurs so that unnecessary distress to relatives and friends can be avoided. The main Buddhist tradition is then for the family to request prayers from the Sangha (usually a monk, nun or priest) of the appropriate School of Buddhism and for positive actions to be performed and dedicated to the dead person.

Particularly for practitioners of Vajrayana Buddhism -most likely Tibetan Buddhism in Scotland - the esoteric practice of Powa or ejection of consciousness may well be performed by an experienced Buddhist practitioner.

\section{Funeral}

Traditions may vary as there are different schools of thought. Buddhists can dispose of the dead body by all four elements- whichever is appropriate to the country and people. However, most Buddhists are cremated and the body should be disposed of within 3-7 days.

\section{Post Mortems}

As in the situation of transplants after death, some patients and relatives may state a prior objection to post mortem due to the belief that the mind may dwell within the body for some time after cardio respiratory death; whereby the body should not be moved for 72 hours, and where disruption of internal organs may be perceived to undermine the optimal dissolution of consciousness.

\section{Contacts}

It should be re-emphasized that the above article serves to purely summarize contemporary guidelines to various health issues from the Buddhist perspective.

If a Chaplain or healthcare professional is seeking more specific guidance, in respect of a patient's particular school of Buddhism, or is seeking to facilitate counselling from a fellow Buddhist practitioner, then they would be encouraged to ascertain, from the patient or family, which specific form or school of Buddhism the patient practices. Thereafter local contact details may be best obtained from the patient. However, if this approach is unsuccessful or felt impractical the following may serve as useful contact resources:

- www.buddhanet.net provides one of the most comprehensive lists of UK Buddhist contacts at:

- http://www.buddhanet.net/euro_dir/eur_sco1.ht $\mathrm{m}$

- The Network of Buddhist Organizations (UK) The Old Courthouse Renfrew Street London SE11 4NB Tel. 01715825797 is a forum for representatives of the many traditions of Buddhism in the UK to meet together and cooperate on matters of common interest. It has 40 member organizations, with contact details on its website. http://www.nbo.org.uk/home.htm

- The Directory of Buddhist Groups and Centres and Other Related Organizations in the United Kingdom and Ireland available from The Buddhist Society, 58 Eccleston Square London $\begin{array}{lllll}\text { SW1V } & 1 \mathrm{PH} & 0171 & 834 & 5858 .\end{array}$ http://www.thebuddhistsociety.org/

Conrad Harvey is Buddhist Representative, NHS Scotland Spiritual Care Committee 